\title{
PRACTICAL GUIDELINES ON CONDUCTING INTERCULTURAL TRAINING AT UNIVERSITY
}

\author{
S.L. Suvorova, alex97@shadrinsk.net, \\ T.V. Khilchenko, tkhill@rambler.ru \\ Shadrinsk State Pedagogical University, Shadrinsk, Russian Federation
}

\begin{abstract}
The article deals with the problem of modern intercultural education in universities. The purpose of the paper is to find an efficient way to develop language skills of the students based on intercultural training. The authors consider algorithms and stages of organizing the intercultural training aimed at the students' independent and co-functioning work accompanied by self- and peer-analysis. The article deals with the attempt to illustrate two models of intercultural training. The main form of intercultural training organization is discussion, the two variants of which are: a natural discussion and a secret role discussion.

Keywords: intercultural education, intercultural education at university, training, intercultural training, natural discussion, secret role discussion.
\end{abstract}

The growth of multicultural education environment is a widespread phenomenon in the sphere of higher education in the 21 st century.

Modernization processes in the field of language education are associated primarily with the requirement of raising a bicultural bilingual, a person who has not only a good command of a foreign language, but is also able to adapt quickly to the cultural peculiarities of the native speakers. Therefore, teaching foreign languages in university is increasingly focused on the modern achievements in the sphere of cultural studies. These provisions largely determine the priority of intercultural education at the university and mean the change of the prepotency from language skills development in favor of teaching how to conduct a dialogue between representatives of different linguistic societies in order to develop a socially active and independent personality of a student. It seems axiomatic that the concepts of "language education", "intercultural paradigm" and "intercultural education" constitute a single terminological field of a general problem, namely teaching and learning modern native and non-native languages and cultures, and language education and intercultural education are considered as conjugate however autonomous integral system components. Many scholars agree on a certain conventionality of the distinction between the concepts of "language education" and "intercultural education" $[1,3,5]$

Intercultural education is currently viewed as a requirement for the successful implementation of language education and the formation of a multicultural linguistic personality capable of speech interaction at the intercultural level. Such ability inevitably occurs in the mode of assimilating the facts of culture in the process of using a language as a means of communication and mastering a language as a means of communication based on the assimilation the facts of culture [8, p. 29-30]. The formation of the "third" culture of an individual is carried out in the educational process on the basis of basic culture by means of "intercultural education", which aims at creating students' new cultural awareness the ability to understand a different way of life, different values, a different approach to one's own values and giving up existing stereotypes and prejudices when students contact with another culture [7, p. 1350].

One of the conditions and methods of intercultural education is intercultural training.

Training in modern pedagogical science is understood both as a form of interactive learning, the purpose of which is to develop the interpersonal and professional communicative competence, and as one of the most important methods in the system of professional and pedagogical training modified into a training for business communication as a type of socio-psychological training aimed at the acquisition of knowledge and skills, correction and formation of motives necessary for successful communication in professional environment.

The specific concept in this respect is a socio-psychological training which is regarded as psychological influence practice, based on group work active methods and has the purpose of building communicative competence, namely 
the development of knowledge, social attitudes, skills and experience in interpersonal communication. Socio-psychological training requires working out clear rules for the group work which traditionally include: the appropriateness of the beginning and the end of the procedure, confidentiality, active engagement of participants, open attitude and the right to say "no", necessity to listen, the right to personal opinion and support, the requirement to speak for yourself and about what is happening right now.

The training method combines the clarity of planning with a large degree of freedom, flexibility of approach and the ability to meet the specific objectives of each interaction act.

At present several types of social and psychological training are distinguished: business communication training, communication skills training, training for certain social and professional groups, etc. We consider it advisable to single out a special type of training - intercultural training, which is understood as the psychological influence practice in situations of intercultural communication in groups, aimed at intercultural communication skills development and gaining behavioral experience adjusted to various social roles.

The main purpose of the intercultural training is the formation of students' internal attitudes regarding the peculiarities of the foreign culture, expanding linguistic and cultural knowledge while discourse creating, gaining experience of a positive attitude towards yourself and communication partners [10, p. 124-128]. In our view, the tasks of such training include:

- improvement of the training participants' socio-psychological competence in the process of intercultural communication;

- development of students' abilities to effectively interact in a group taking into account the suggested problem of intercultural communication and the list of social roles;

- formation of an active social position and development of abilities to view a communication partner in a positive way;

- raising the level of students' professional and pedagogical culture;

- development of intercultural communication skills based on the comparison of two (three or more) cultures, i.e. development of crosscultural competence;

- updating theoretical knowledge in Linguistics, Psychology, Pedagogy and Culture studies.

Based on A.S. Prutchenkov's research [11], we believe that the organization of intercultural training should be based on the following particular principles [6]:

1. The principle of dialogization of intercultural interaction in a discursive mode, which implies equal and full active participation of all members of the training group in the discussion of proposed problems.

2. The principle of constant feedback, which means that each participant continually receives information from other members of the group and corrects the methods of intercultural communication based on structuring various types of discourses.

3. The principle of self-monitoring that means the disclosure by each member of the group of the peculiar features of personality in intercultural interaction in the process of discourse perception and creation.

4. The principle of harmonization of cultural, intellectual and emotional spheres of the training participants, which is realized in the form of a group discussion.

5. The principle of voluntary participation, based on the students' awareness of the need for training and on the internal interest in its results.

6. The principle of constant composition of the group, combined with the principle of heterogeneity (grouping people who differ in gender, degree of acquaintance, level of preparation, etc.).

7. The principle of immersion, meaning the organization of training activities in large temporary blocks-immersions.

Organizing training with reference to these principles allows activating the processes of interpersonal and intercultural communication of students in accordance with the current level of their knowledge and competence in building a communicative act of discursive nature, with their social attitudes. Within the intercultural training one can distinguish two types that are significant for our research-mutual perception and comprehension training and persuasive impact training. The first type of training provides an opportunity to "temporarily consolidate the experience of communication".

From the standpoint of our research, the mutual perception and comprehension training ensures the formation of students' perceptual skills and improvement of listening skills. The persuasive impact training involves memorizing and using the speech clichés of a debatable nature for creating discourse in terms of extra linguistic factors $[2,4]$. 


\section{Теория и методика профессионального образования}

The main form of intercultural training organization is a discussion, the two variants of which seem to us as the most appropriate ones: a natural discussion and a secret role discussion.

The traditional way of organizing a discussion involves the following stages [9]: 1) orientation - defining goals and topics for discussion, choosing a problem for discussion; 2) information gathering on the problem; 3) choosing alternative solutions of the problem; 4) holding out the discussion; 5) streamlining, justification and collective assessment of the information obtained during the discussion; 6) the final phase - drawing the conclusion.

Natural discussion as a form of intercultural training requires preliminary preparation that includes: choosing the style of conducting the training (free management, programmed management, compromise form); mastering psychological and pedagogical knowledge, individualized methods of interpersonal interaction at the intercultural level by the participants of the training; formation of students' views about the basic parameters and principles of intercultural socio-psychological training; assimilation of lexical units and formulas (cliché for discussion) by students; analysis of discourse parameters for further discussion based on it.

To organize a natural discussion, the facilitator needs to identify the problem to be discussed, divide it into several key problem assignments, form a heterogeneous group for the training, set the time parameters for the training, familiarize the participants with the activity rules during the training. In a natural discussion, the initiative is completely in the hands of the training participants, the teacher only writes down opinions, determines the nature of mistakes (language, speech, errors associated with the interference of the students' native language and culture, etc.). At the end of the training, conclusion drawing is held with hearing the opinions about the discussion itself.

Secret role discussion involves the analysis of the training participants' mutual impressions of each other and the proposed problem. The main purpose of such a discussion as a form of intercultural training is, in our opinion, the formation of students' skills of comparison, adaptation and assimilation of the cultural norms of the two systems: native and foreign in the mode of reincarnation - taking on a different social role. We consider the "Aquarium" method as one of the most interesting variants for holding such a discussion. The authors developed and approbated the "Aqua- rium" method while teaching students foreign language culture based on discourse.

The method of "aquarium" involves the organization of training in a group divided into two subgroups: one is inside the "aquarium", the other is watching from the outside. For the group inside the "aquarium", the following roles are suggested: the organizer, the debater, the eccentric, the ringleader, the compromiser. The training participants are informed in advance about the peculiar features of roles.

The discussion can be held on any topic, however, from the standpoint of our research, it is advisable to choose a topic involving the comparison of two cultures, for example, "Problems of the Youth in Different Countries". Training participants with roles are inside the "aquarium" and are located in the center. Around them are the other members of the group whose task is to participate in the discussion: to agree or disagree with the opinion of the group in the center. Only the participants in the "aquarium" know about the roles, the task of the rest is to determine at the end of the discussion which roles were played and how well the students inside the "aquarium" coped with them.

The value of this method lies in the fact that students learn to take on roles that do not coincide with their actual roles in various subcultures and social groups, as well as express opinions depending on the role proposed in a different cultural environment.

Intercultural training in the form of discussion with hidden roles contributes to the development of psychological competence of students, the ability to take on various social roles that are different from their roles in everyday life, the actualization of language knowledge and skills in situations of intercultural communication. Intercultural training is aimed at the practical mastering of values, norms, rules of representatives of another culture. Two priority tasks are clearly distinguished: to acquaint students with intercultural differences in interpersonal relations, which requires participation in playing situations that take place differently in different cultures; makes it possible to transfer the knowledge gained to new situations, which is achievable if the student acquaints himself with the most characteristic features of another culture.

The recommended techniques of conducting the training include traditional group work procedures, such as psycho-gymnastic exercises, reflection of experience, discussions, interactive 
modeling, role-playing, simulation, group discussions. Using these techniques allows to prepare the participants for effective contacts with other cultures, to teach them to understand, feel and analyze both their own behavior and the behavior of members of other cultures.

Practical guidelines on conducting intercultural training in university allow the teacher to organize an educational process of teaching foreign languages and cultures with a focus on current global trends.

This research has been funded by the FS source on the topic "Cluster model of multilingual training of high school students".

\section{References}

1. Amir H.A. An Investigation into the Benefits of the Intercultural Approach to EFL Learning and Teaching: A Case Study of Taif University, KSA. Journal of Language Teaching and Research, 2017, vol. 8, no. 1, pp. 52-63. DOI: $10.17507 / \mathrm{jltr} .0801 .07$

2. Barnes M.E. Encouraging Interaction and Striving for Reciprocity: The Challenges of Community-Engaged Projects in Teacher Education. Teaching and Teacher Education, 2017, vol. 68, pp. 220-231. DOI: 10.1016/j.tate.2017.09.004

3. Galante A. Intercultural Communicative Competence in English Language Teaching: towards Validation of Student Identity. BELT Journal, 2015, no. 6(1), pp. 29-39. DOI: 10.15448/2178-3640.2015.1.20188

4. Gurney L., Liyanage I. Managerialist Vis-à-Vis Learning and Development Goals for EAL Teachers: a Case Study of an In-Service Professional Development Provider. International
Journal of Pedagogies and Learning, 2015, vol. 10, iss. 1, pp. 38-46. DOI: 10.1080/22040552.2015. 1084675

5. Hastjarjo S., Nuryana A. Intercultural Communication Training in Vocational and Industrial Education Training. IOP Conference Series: Materials Science and Engineering IOP Conference Series: Materials Science and Engineering, 2018, vol. 306, pp. 124-128. DOI: 10.1088/1757-899x/306/1/012115

6. Karbysheva K.S., Nikonova E.D., Kobzeva N.A. [Teaching Foreign Languages on the Basis of an Intercultural Approach]. Young Scientist, 2015, no. 11, pp. 1350-1352. (in Russ.)

7. Kontseptsiya akademicheskoy mobil'nosti $v$ Rossiyskoy Federatsii [The Concept of Academic Mobility Development in the Russian Federation]. Available at: http://intpr.ntf.ru/DswMedia/ koncepciyaakademicheskoymobil-nosti_itog.pdf (accessed 20.10.2018).

8. Marasanov G.I. Sotsial'no-psikhologicheskiy trening [Socio-Psychological Training]. Moscow, Kogito-Tsentr Publ., 2001. 251 p.

9. Mickenbecker-Soubai B. Interkulturelles Lernen. Frühes Deutsch, 2004, pp. 10-13.

10. Prutchenkov A.S. "Svet moy, zerkal'tse, skazhi ...": metodicheskie razrabotki sotsial'nopsikhologicheskikh treningov ["My light, mirror, say ...": methodical development of social and psychological training]. Moscow, Novaya shkola Publ., 1996. 144 p.

11. Suvorova S.L. Formirovanie kommunikativno-diskursivnoy kul'tury budushchikh uchiteley. Diss. dokt. ped. nauk [The Formation of Communicative-Discursive Culture of Future Teachers. Diss. Doct. (Pedagogy)]. Chelyabinsk, 2005. $380 \mathrm{p}$.

Received 28 December 2018

Удк 378.444

DOI: 10.14529/ped190106

\title{
ПРАКТИЧЕСКИЕ РЕКОМЕНДАЦИИ ПО ПРОВЕДЕНИЮ МЕЖКУЛЬТУРНЫХ ТРЕНИНГОВ В УНИВЕРСИТЕТЕ
}

\author{
С.Л. Суворова, Т.В. Хильченко
}

Шадринский государственный педагогический университет, г. Шадринск, Россия

В статье рассматривается проблема современного межкультурного образования в университетах. Цель статьи - найти эффективный способ развития языковых навыков студентов на основе межкультурных тренингов. Авторы рассматривают алгоритмы и этапы организации межкультурного обучения, направленного на самостоятельную и совместную работу студентов, сопровождающуюся самоанализом и анализом со стороны преподавателя. 


\section{Теория и методика профессионального образования}

В статье рассматриваются две модели организации межкультурного тренинга. Основной формой организации межкультурного тренинга является дискуссия, двумя вариантами которой являются естественная дискуссия и дискуссия со скрытыми ролями.

Ключевые слова: межкультурное образование, межкультурное образование в университете, тренинг, межкультурный тренинг, естественная дискуссия, дискуссия со скрытыми ролями.

\section{Лumepamypa}

1. Amir, H.A. An Investigation into the Benefits of the Intercultural Approach to EFL Learning and Teaching: A Case Study of Taif University, KSA / H.A. Amir // Journal of Language Teaching and Research. - 2017. - Vol. 8, no. 1. - P. 52-63.

2. Barnes, M.E. Encouraging interaction and striving for reciprocity: The challenges of communityengaged projects in teacher education / M.E. Barnes // Teaching and Teacher Education. - 2017. Vol. 68. - P. 220-231.

3. Galante, A. Intercultural communicative competence in English language teaching: towards validation of student identity / A. Galante // BELT journal. - 2015. - No. 6 (1). - P. 29-39.

4. Gurney, L. Managerialist vis-à-vis learning and development goals for EAL teachers: a case study of an in-service professional development provider / L. Gurney, I. Liyanage // International Journal of Pedagogies and Learning. - 2015. - Vol. 10. - Iss. 1. - P. 38-46.

5. Hastjarjo, S. Intercultural Communication Training in Vocational and Industrial Education Training / S. Hastjarjo, A. Nuryana // IOP Conference Series: Materials Science and Engineering IOP Conference Series: Materials Science and Engineering. - 2018. - Vol. 306. - P. 124-128.

6. Карбышева, К.С. Обучение иностранным языкам на базе межкультурного подхода / К.С. Карбышева, Е.Д. Никонова, Н.А. Кобзева // Молодой ученый. - 2015. - № 11. - С. 1350-1352.

7. Концепџия академической мобильности в Российской Федераџии. - http:// intpr.ntf.ru/ DswMedia/koncepciyaakademicheskoymobil-nosti_itog.pdf (дата обращения: 20.10.2018).

8. Марасанов, Г.И. Социально-психологический тренинг / Г.И. Марасанов. - М.: КогитоЦентр, 2001. - 251 c.

9. Mickenbecker-Soubai, B. Interkulturelles Lernen / B. Mickenbecker-Soubai // Frühes Deutsch. 2004. - P. 10-13.

10. Прутченков, А.С. «Свет мой, зеркальие, скажи ...»: методические разработки сочиальнопсихологических тренингов / А.С. Прутченков. - М.: Новая школа, 1996. - 144 c.

11. Суворова, С.Л. Формирование коммуникативно-дискурсивной культуры будущих учителей: дис. ... д-ра пед. наук / С.Л. Суворова. - Челябинск, 2005. - 380 с.

Суворова Светлана Леонидовна, доктор педагогических наук, профессор, профессор кафедры теории и практики германских языков, Шадринский государственный педагогический университет, г. Шадринск, alex97@shadrinsk.net.

Хильченко Татьяна Викторовна, кандидат педагогических наук, доцент, доцент кафедры теории и практики германских языков, Шадринский государственный педагогический университет, г. Шадринск, tkhill@rambler.ru.

Поступила в редакцию 28 декабря 2018 2.

\section{ОБРАЗЕЦ ЦИТИРОВАНИЯ}

Suvorova, S.L. Practical Guidelines on Conducting Intercultural Training in University / S.L. Suvorova, T.V. Khilchenko // Вестник ЮУрГУ. Серия «Образование. Педагогические науки». - 2019. - Т. 11, № 1. - С. 48-52. DOI: $10.14529 /$ ped190106

\section{FOR CITATION}

Suvorova S.L., Khilchenko T.V. Practical Guidelines on Conducting Intercultural Training in University. Bulletin of the South Ural State University. Ser. Education. Educational Sciences. 2019, vol. 11, no. 1, pp. 48-52. DOI: $10.14529 /$ ped190106 